Kohl: a Journal for Body and Gender Research

Vol. 2, No. 2 (Winter 2016)

\title{
Gendered Voices of Youth and Tahrir in Ahdaf Soueif's Cairo: My City, Our Revolution
}

\author{
Deema Nasser
}

\begin{abstract}
:
This essay is a critical reading of feminist representations of voice and nation in Ahdaf Soueif's political memoir Cairo: My City, Our Revolution (2012) which critiques its attentiveness to both gender-inflected and family-oriented imagery. Relying on major theoretical works on autobiography and Egyptian feminism, and critical reflections of Egyptian women's writing and the 2011 Tahrir Revolution, this essay situates Soueif's personal and political account of the revolution at the edge of a long tradition of women's resistance writing in Egypt. This essay also problematizes the memoir's claim to representation because of political considerations that privilege a Western readership over a local one, despite its attempt to ingratiate itself with hybrid autobiographical writing across many intertextual mediums, a movement in contemporary Egyptian literature that has intensified since the beginning of the $21^{\text {st }}$ century, revealing a need and urgency for the self-affirmation of voice and documentation of history from people's perspectives as revolution unfolds.
\end{abstract}


In the wake of the 2011 Tahrir Revolution, Ahdaf Soueif asks a question that encapsulates a significant paradigm shift characterizing Egyptian literary production in the early $21^{\text {st }}$ century: where has fiction gone? With the culture of storytelling in overdrive around critical moments of social and political transformation culminating in revolution, writers, artists, and cultural actors have been turning to nonfictional forms of writing in genres that exceed the traditional novel in order to resurrect voices that have been previously silenced in the Egyptian literary and political spheres. This economy of literary production, which takes place vis-à-vis an age of political participation and activism, new media, and world literature, is dubbed by literary critics like Tarek el-Ariss as "new writing" and comes as a reaction to the 1990s generation of selfdeconstructionist writing that casts doubt on the effectiveness of political commitment in the aftermath of the 1967 June War. ${ }^{1}$ Previously unknown writers and artists who foreground popular voices as acts of literary resistance to social and political injustice are becoming more vocal and visible since the events of 2011-2013 in Cairo, a phenomenon that has been qualified as a democratization of "the revolutionary 'republic of letters."'2

With a substantial body of work on the Egyptian uprisings already in circulation, very little fiction has been attempted, which Soueif chalks up to "the immediate truth [being] too glaring to allow a more subtle truth to take form" in a piece written for The Guardian in 2012. Roger Bromley picks up on a similar note in his article "'Giving Memory a Future:' Women, Writing, Revolution" (2015), saying that "many of the writers have spoken about the difficulty of writing fiction during the uprisings, and of the need to participate actively in them by other means" (222). Aside from a decent work of fiction that reflects the complexity of Egypt's uprisings needing time, space, and perspective to formulate, the 2011 Tahrir Revolution presented itself as an opportunity for writers to reaffirm their political commitment and rewrite the history of the people's tahrir (liberation) as it was unfolding, thereby historically legitimating it from a popular perspective and challenging official discourses by the government and mainstream media. Banking on an award-winning career in novel and short story writing since the late 1980s, Soueif negotiates a space for herself among these new writers with her recent political memoir, Cairo: My City, Our Revolution (2012). She narrativizes the public account of the revolution in its first year in a journalistic style through the private lens of memory and family dynamics, defying conventional expectations of the memoir genre. Key to the narrative is the projection of a seemingly pro-feminist image of revolutionary activism and the city that nurtured it, but upon closer inspection, the critical reader can see that Soueif reinscribes neo-patriarchal roles to women as bearers of family and nation. Although the memoir takes up a local subject matter and contextualizes itself within verifiable private and public spaces in Cairo, Soueif's preoccupation with a Western readership overcasts her social responsibility as an Arab woman and Anglophone writer in diaspora to depict historically- and culturally-specific accounts of the Egyptian revolution and local activism. This responsibility is especially heightened when considering the many Egyptian writers and bloggers, both men and women,

\footnotetext{
${ }^{1}$ See Tarek el-Ariss' article, "Fiction of Scandal," in the Journal of Arabic Literature 43.2/3 (2012) for more on the new generation of writers as opposed to the generation of defeatist authors and the ideology of hazimah (defeat) which informed their writing. Examples of works that dismantle post- 67 motifs of alienation and/as political distance include, Ahmad Alaidy's An takūn 'Abbās al-'Abd (Being Abbas el Abd, 2003).

2 See Rita Sakr's Anticipating the 2011 Arab Uprisings: Revolutionary Literatures and Political Geographies (2013).
} 
such as Ghada Abdel Aal and Alaa Abdel Fattah, who were simultaneously writing and reporting on the Tahrir Revolution in Arabic and reaching substantial reading/viewing publics in Cairo. ${ }^{3}$

Literature has never been divorced from addressing injustice on the social and political levels, but in the new century, there is a more palpable directness and urgency to represent push-back against state despotism in innovative ways. A "hybrid autobiographical genre" that combines memoir and autobiography with the diurnal form comes to the fore among Egyptian writers who represent the 2011 revolution. ${ }^{4}$ The diurnal is utilized as a medium in which political activism is reconciled with private testimonies as occurs in Mona Prince's Ismi thawra (Revolution is My Name, 2012). ${ }^{5}$ The diary form was not prominent among earlier Egyptian autobiographies, a form well-established in previous generations, as Dina Heshmat explains in her 2015 article, "Egyptian Narratives of the 2011 Revolution: Diary as a Medium of Reconciliation with the Political" (68-69). This new writing justifies the turn away from fiction toward a style that is simultaneously personal yet public, honest, quick and direct, bordering on journalism in order to personalize the political and capture the moment of uprising. It is within this context and culture of instantaneous publicity that Cairo finds a voice of its own in 2012 after the Tahrir Revolution was already a year old, belonging instantly to a global readership just as much as it does to a local one. ${ }^{6}$ Therefore, Soueif's privileged positionality and her claim to social responsibility as a writer warrant a closer analysis and interrogation of which voices are accentuated over others, situating the memoir at the interstice of a long tradition of revolutionary Egyptian women's writing from a feminist, gender-based, and family-oriented perspective.

\section{Egyptian Feminism(s) from Within and Without: A Brief History}

The analysis of revolutionary voices represented in Cairo, beginning with Soueif's own autodiegetic voice, demands that we question the gender politics governing the narrative(s) of popular resistance and the language(s) of tahrir in the text. In order to do so, the text ought to be situated within - or possibly at the verge of - the history of female activism and memoir-writing in Egypt. It is important to note, however, that this historicization belongs to a larger discussion of Arab and Islamic feminisms that still occupies a central area of debate among critics and scholars of Middle Eastern women studies, and lies beyond the methodological scope of this essay.

\footnotetext{
${ }^{3}$ See Jack Shenker's piece "Egyptian activist Alaa Abd El Fattah accuses army of hijacking revolution" and Razia Iqbal's "Egyptian writers on the "unfinished revolution"' in The Guardian.

${ }^{4}$ The term is first introduced by Hala Kamal in "Women's Memoirs of the Egyptian Revolution: Mona Prince's Ismi thawra and Ahdaf Soueif's Cairo: My City, Our Revolution" (586).

${ }^{5}$ Prince uses the diurnal to document her initial hesitance to join the first 18 days of revolution (Heshmat 69), while Soueif uses it to register her firm faith in activism from the start.

${ }^{6}$ The US edition is entitled, Cairo: Memoir of a City Transformed. The book also appears in a third edition under the name Cairo.
} 
In her article entitled "Arab Feminisms" (2010), Anastasia Valassopoulos identifies several tendencies of reading and understanding the waves of feminist thought and ideological discourse in the Arab and Islamic worlds based on the historical, political, economic, cultural, and religious factors that have influenced their shapes, especially in light of the 1990s wave of Islamic fundamentalism. ${ }^{7}$ Despite their problematic orientalizing framework of application, there still remain several postcolonial readings of Arab and Islamic feminisms, especially among Western scholars of the Middle East, that over-emphasize the historical, economic, and political roles played by colonialism and posit Islamic feminism as a reactionary alternative to Western-informed models of modernity in the region (Valassopoulos 206-7). Similarly, in The Postcolonial Arabic Novel: Debating Ambivalence (2003), Muhsin al-Musawi situates feminist politics and poetics in the "Arab world" at large within postcolonial theory because of the common arches of confrontation with patriarchy, the search for a legitimating origin or ancestry, and the manipulation of circumstances to establish identity as resistance to colonial contamination (221). On the one hand, this understanding of Arab and Islamic feminism homogenizes women's experiences among different Islamic cultures in the region. It does not account for dissenting Islamic visions and ideologies among women, which are products of political and economic considerations specific to each nation. On the other hand, it disregards other forms and expressions of Arab feminism that exist outside an interpretive Islamic framework. A third approach, which manifests itself in the case of the Cairo memoir, stresses the "significance of listening to [women's] popular voice[s] in the Arab world for what [they] might teach us" as opposed to focusing exclusively on the voices of intellectual women in the Arab world and the diaspora (209). While Valassopoulos views different forms of visual media (film, television, and social media networks) as platforms that represent popular women's voices, my analysis focuses instead on textual representations of women in light of Egypt's 2011 revolution. Closely reading women's voices in Soueif's memoir in relation to their social classes, age groups, intellectual levels, and religious backgrounds reveals that "there are multiple voices clamoring for recognition" and that Egyptian feminism is far from monolithic (Valassopoulos 209). ${ }^{8}$ This, in turn, calls for a brief excursion on the waves of Egyptian feminism in order to cultivate a more nuanced approach to the upcoming reading of popular women's voices in Cairo.

Margot Badran's now classical text Feminists, Islam, and Nation: Gender and the Making of Modern Egypt (1995) identifies a grassroots Egyptian "feminist consciousness" that dates back to written discourse emerging in the late $19^{\text {th }}$ century at the hands of cross-class women from various religious backgrounds, who are now considered foremothers to contemporary feminist movements in Egypt. It is crucial to note that the forerunners of feminist discourse in Egypt, such as Zaynab Fawwaz and Aisha al-Taymuriyah, did not adopt the term "feminist" in their writings, nor did they explicitly self-identify as such. Hoda Shaarawi and Nabawiyah Musa, both keystone figures in $20^{\text {th }}$-century Egyptian feminist movements, also furthered

\footnotetext{
7 The texts which Valassopoulos synthesizes arguments for and against are: Lila Abu-Lughod's Remaking Women: Feminism and Modernity in the Middle East, Margot Badran's Feminism in Islam: Secular and Religious Convergences, Miriam Cooke's Women Claim Islam: Creating Islamic Feminism through Literature, Mona Mikhail's Seen and Heard: A Century of Arab Women in Literature and Culture, and Haideh Moghissi's Feminism and Islamic Fundamentalism: The Limits of Postmodern Analysis.

8 Valassopoulos also discusses the rise of Islamic feminism on a transnational level as a counter-discourse to Western narratives of Islamophobia. For more detail, see "Arab Feminisms," 208-209.
} 
women's empowerment for a long time before they labeled themselves and were labeled as feminists. The term "feminist writing" was therefore attached to their work and activism in retrospect. 9

The common misconception Badran attempts to redress in her historiographic study is the view that Egyptian feminism emerged as a subtext of colonialism and modernization - or "Western discourse" - in Egypt during the $19^{\text {th }}$ century (24). Condemning Egyptian feminism to a homogenous and essentializing narrative, this view is compatible with Western perceptions of Egyptian women as subjects with identities informed solely by their postcoloniality, classifying them into either conservative Islamists or liberal secularists, and confining them to polarizations like "reactionary" as opposed to "progressive." The story Badran tells suggests that burgeoning feminist discourse in Egypt in fact emerged organically out of Muslim, Christian, and Jewish middle and upper-class women's gradual realization that their social and religious freedoms and rights in their personal and public lives had been largely inhibited by the patriarchs of their society. Before nationalist struggles, Egyptian women's first and more pressing burden, therefore, was the institutionalized patriarchal hold on their daily lives. ${ }^{10}$ Despite its inevitable ceiling, women's education in the early $19^{\text {th }}$ century under Mohammad Ali Pasha's semi-autonomous rule played an important role in drawing their attention to the rights they were being denied - the right to have an occupation, to attend social functions without the company of men, to remain unveiled, to participate in political life, etc. Their initial expressions of anti-patriarchal struggle therefore took place in the context of home and family. It was not until the late $19^{\text {th }}$ century, particularly after 1882 when British colonial forces occupied Egypt, and what meager rights women had towards education that feminist discourse wielded a nationalist dimension alongside intellectual men's discourse on Egyptian nationalism: "Colonialism rendered Egyptians, men and women alike, nameless and nationless, while together they were gendered female. It was no accident that the recognition of 'Egyptianness' and of gender arose simultaneously" (Badran 12). The rhetoric of prominent male intellectual figures, both Muslim and Christian, secular and Islamic, the likes of Qasim Amin, Sheikh Muhammad 'Abduh, and Murqus Fahmi, called for the importance of women's education, empowerment, and liberation to further nationalist and anticolonial causes against British occupation. ${ }^{11}$ The dominant view among these men was that "family despotism is mirrored in state despotism. Lack of family unity is reflected in lack of national unity" (18). In other words, they argued that Egypt was dominated by foreign colonial powers because Egyptian women and mothers were underrated and subordinated in the hierarchy of power. Nationalist feminist discourse, both Islamic and secularist, greatly benefited from the support of its male counterpart, culminating in the 1919-1922 confrontation

\footnotetext{
9 Badran uses the Arabic term "nisa'i" to denote the label "feminist" which was applied to the circulating works on women's liberational demands in the 1920's, especially after the establishment of al-Ittihad al-Nisa'i al-Misri (The Egyptian Feminist Union) in 1923 by Hoda Shaarawi, which was when they first used the term "feminist" to describe themselves (19).

${ }^{10}$ Al-Musawi attributes these patriarchal practices to a resilient Ottoman legacy in the early $20^{\text {th }}$ century (44).

${ }^{11}$ A widely circulating name for such reformist Arab intellectuals is Nahdawis, pertaining to the late $19^{\text {th }}$ - and early $20^{\text {th }}$-century Nahdah (Arab Awakening and Modernity) intellectual movement, in which multiple narratives of nationalism, liberation from colonial powers, and modernization emerged in Egypt and other cultural-intellectual centers in the Arab world, like Lebanon and Syria. While some embraced a self-orientalizing stance subservient to Western liberalism and modernization, others referred back to a reformed religious identity as a springboard towards nationalism and modernism. See al-Musawi (37-41).
} 
between the Egyptian nationalist Wafd party and the British forces, in which women activists played a significant role. However, after Egypt claimed its independence, the discourse of female equality and liberation diminished considerably once men started competing among themselves for political power.

It is important to note that while there are two large umbrellas under which the development of Egyptian feminist discourse took place, namely Islamic and secular, the different language, class, and temporal divisions among feminists resist framing the heterogeneous waves of feminism within a conservative Islamic-liberalist dichotomy. ${ }^{12}$ Furthermore, the evolution of feminist thought in the late $19^{\text {th }}$ century through a reformed Islamic lens does not coincide with the more contemporary wave of politicized populist Islam that has swept through Egypt since the 1970s, which Alaa al-Aswany argues is not inherent to Egyptian religious convictions and serves political interests in On the State of Egypt: What Made the Revolution Inevitable (75-6). The former emerged out of an advocacy of women (and men) to pursue the individual study of Islam, which encourages uninhibited interpretation and revision of certain previously-held social conventions and practices that were thought to be religious prescriptions, such as the domestication and veiling of women (Badran 11). ${ }^{13}$ The latter, however, is the result of the growing influence of Gulf oil states, particularly Saudi Arabia, which led to the infiltration of Wahhabist ideologies into Egyptian society, an extremely conservative form of Islam that focuses on the externals of religion - the appearance and performative practices of piety - rather than the core values of ethics and morality (al-Aswany 104). Under this retrogressive interpretation of Islam, which coincided with the protracted Mubarak term, women have been secluded behind much stricter social rules and treated as objects of sexual desire that must be veiled from sight, literally and figuratively.

That is not to say that there have not been any conservative Islamic women in Egypt before the 1970s; the multifarious religious sub-divisions in Egyptian society, Islamic or otherwise, are beyond the scope of this essay. What is important to note is that the history of Islamic feminism in Egypt is not an oxymoron as Badran explains in a recent interview for France 24 News in December 2011. ${ }^{14}$ Women's feminist and religious identities were not in conflict; they developed in tandem with one another. ${ }^{15}$ Understanding the history of Egyptian women's feminisms as a phenomenon that transcends religious, class, and language

\footnotetext{
${ }^{12}$ Al-Musawi also points out in "Women in Arabic" that despite the strong rhetoric of male feminism that supported women's liberation demands in Egypt (and the Arab world) in the early $20^{\text {th }}$ century, Arab Marxists have also critiqued an equally strong pseudo-colonial counter-discourse of the privileged and moneyed classes, which fetishizes and desires the female body and everything it symbolizes in the nation (211-12).

13 The practice of individual study and inquiry of Islam (also known as ijtihad) is one of the arguments made by Sheikh Muhammad 'Abduh, and for which he was highly criticized by conservative Islamists.

14 The distinction between women articulating feminist agendas through an interpretive Islamic framework (i.e. Islamic feminism) and the contemporary wave of extreme fundamentalist Islam in Egypt (Salafism, etc.) cannot be over-emphasized. In fact, it is one of Badran's arguments in Feminism in Islam (2009) that Islamic feminism can be seen as a contemporary cross-nationalist politics that opposes repressive fundamentalist Islam in Egypt and elsewhere.

15 In 2011, Tahrir Square witnessed a mélange of feminist ideas and collaborative practices among women in labor movements and Islamist organizations as well, however, the focus by mainstream feminist groups within Egypt and in Western media, was on liberal and secular feminist movements. See Catherine Sameh's "Activism and the Academy: Feminisms in the World."
} 
barriers, and that has emerged in its own organic narrative(s) allows us to see that "women's commitment to nationalism was, if anything, heightened by [not blinded by] their feminism" (Badran 13). ${ }^{16}$ Shaarawi's memoir, Harem Years: The Memoirs of an Egyptian Feminist, 1879-1924, is one such example that crosses over between her personal and political life in the early $20^{\text {th }}$ century, and culminates in the feminist activist's experience organizing and participating in the women's demonstration against British occupation in the 1919 nationalist revolution. In an article from Al-Ahram, Mahmoud el-Wardani makes the point that "a century after the fight for rights, Hoda Shaarawi's memoirs are a reminder that women are necessary for political fights - such as Egypt's [2011] revolution" ("Re-published: Hoda Shaarawi Memoirs on Birth of Egypt's Feminism"). ${ }^{17}$ The interesting fact here is that it was republished two years after the 2011 revolution in Tahrir Square, which indicates a surge of interest in personal literature (the memoir) to capture events that affect public national history (revolution). The following section closely traces how this complex history of local Egyptian feminisms is diluted by the problematic politics of gender in Soueif's Cairo memoir, a text commissioned by the West (Bloomsbury UK) for Western readers who are interested in revitalizing outdated postcolonial portraits of Egyptian women.

\section{Masr: The Nation as Woman; Gender Politics of Resistance and Liberation}

It is in relation to this long and varied tradition of women's writing that we ought to visualize and interpret the representations of revolutionary women made in Cairo. Women are particularly vocal in Soueif's memoir and there is no denying that they play an active role in the street and in her narrative, beginning with Soueif herself. Although certain cases of autobiographical writing make use of the second and third person to "mask" the identity of the author/narrator, this memoir is clearly autodiegetic from the outset. Contrary to the trend in "veiled autobiographies," popular among Arab novelists in the early $20^{\text {th }}$ century as al-Musawi explicates, in which writers "distance themselves while simultaneously criticizing party politics in its patriarchal formations," Soueif's explicit, politically-engaged memoir breaks down the traditional barrier of authorial and intellectual detachment (53). There is no confusion or renunciation of her own identity as an Egyptian woman, writer, journalist, mother, and activist; in fact, her appeal to Western readers relies on this compound identity being clearly demarcated from the start. She is both writer and citizen, and bears the responsibility of both roles, which explains the transformation of her literary style as well as subject matter from her previous fiction novels with concerns about coming to terms with ambivalent intercultural identities (In the Eye of the Sun, 1992; The Map of Love, 1999) into a locally-contextualized and hard-hitting memoir with inflections of a diurnal form that is not concerned with having a beginning, middle, and end plotline (Heshmat 68).

\footnotetext{
${ }_{16}$ Badran explains that while most upper-class women were fluent in French, English, and German, lower and middle-class women spoke and wrote mostly in Arabic.

17 See also Tahia Abdel Nasser's "Women's Revolution and Tahrir Memoirs" in Al-Ahram Weekly for a history of women's activism in Egypt in the past century leading up to the 2011 revolution.
} 
In the preface, Soueif explicitly states that her identity encapsulates both writer and activist, and throughout the course of writing the memoir she easily moves back and forth between both:

[I]n February 2011, I was in Tahrir, taking part in the revolution, and reporting on it .... It proved impossible to sit in a corner and write about the revolution .... So I tried to "revolute" and write at the same time. (xiii and xiv)

By doing so and in keeping with the conventions of memoir-writing, she effectively collapses the distance between her selves as narrator and protagonist, which is usually protracted in novels, and does not aim to tell a whole life story - only the story of a revolution unfolding in time and space. ${ }^{18}$ Soueif, therefore, strikes a contract with her readers, which allows them to expect a level of fidelity to the course of events because of the complex identity she evokes with her undersigned proper name and time stamps, mimicking the form of diary writing, as well as references to real places and people, an aspect of autobiographical writing Philippe Lejeune privileges in his classical theoretical text The Autobiographical Pact (1974; translated by Katherine Leary, 1989).

But which women are being represented, and what is the nature of the memoir's most striking female imagery? Realistic representations of sexual harassment before the Tahrir Revolution in popular protest movements are left out of Soueif's utopian portrayal of female activism. This is also the case with similarly themed autobiographical writings on the 2011 revolution, as Heshmat explains: "The dynamics of gender alienation and oppression are even muted here, making public space feel more open for women" (70). Throughout the narrative, it can be argued that Soueif's revolutionary feminist rhetoric projects an image of women as strong, subversive, and independent activists simultaneously inscribed in traditional roles as mothers, sisters, and daughters, or as symbols of the nation, which evokes the nationalist patriarchal iconography of the early $20^{\text {th }}$ century. In Egypt as a Woman: Nationalism, Gender, and Politics (2005), Beth Baron recalls the history of the iconic sculpture by Mahmud Mukhtar called Nahdat Misr (The Awakening of Egypt), an award-winning model that was transformed into a monumental work which juxtaposes two figures - a Sphinx rising and a peasant woman unveiling. Baron explains:

The Sphinx and the woman both represent Egypt: the Sphinx rising suggest a rebirth of Egypt's ancient grandeur; the peasant woman lifting her veil symbolizes the liberation of the modern nation. The linking of the two figures - the woman's hand rests on the Sphinx's head - connect antiquity to the present. (68)

\footnotetext{
18 Soueif expresses an anxiety to capture through her own voice the revolutionary moment in the present before it passes her (and the world) by. She says, "I could not write what was fast becoming the past without writing the present" (xiv).
} 
Mukhtar's sculpture was unveiled in the public square of the Cairo train station in 1928, captivating passers-by, local and foreign. It became the symbol of national struggle and was inspired by the 1919 revolution in which women played a significant and active role (67). ${ }^{19}$

The downfall of contemporary feminists like Soueif rehashing nationalist discourse in their representations of women, as al-Musawi argues, is that it always collapses the nation and the woman's body: "In the nationalist discourse of war and chivalry, land is equated to the female body, and both are held sacred" (212). The nation-as-woman metaphor is a phenomenon that is not particular to Egyptian nationalism and resistance to colonial powers, but one for which Baron finds origins in Egypt in the late-19th and early-20th century Nahdah. Baron speaks of the paradox between allegorizing the nation as a woman in the elite male nationalist imaginary while restricting their sociopolitical participation (1-2), a paradox that is only halfway resolved in the Cairo memoir. As I have already mentioned, women are particularly vocal and active in Soueif's text; however, their mobilization is oftentimes framed within familial rhetoric. Baron identifies the discursive practice of metaphorically associating the dynamics of a nuclear bourgeois family with the hierarchy and structures of the nation-state as a universal phenomenon: "Once the nation was envisioned as a family, the concept of family honor could easily be appropriated as the basis for national honor," both very much modern constructs (7 and 40 ). In particular, the discourse on honor (sharaf) was initially a state discourse that nationalists in Egypt later appropriated to further their political causes (42). As for the association of nations and homelands with the feminine gender, it is a phenomenon that stretches back beyond the age of empires and colonies. In the case of Egypt, the Arabic term Masr (Misr) is gendered female, as is the term for a collective community 'Umma (7). While feminists and female nationalists are two distinct concepts, their intersection is particularly intensified in times of revolution, especially when the fight against colonial oppression in 1919 necessitated female activists to serve their role as "Mothers of the Nation" charged with breeding the national youth who will liberate Egypt (Baron 39). Echoing this maternalistic sentiment, Soueif represents herself and her generation of Egyptians as activists and as proud mothers of the young generation of brave revolutionary shabab (which refers to a collective body of young people, either gender-neutral or exclusively male) leading the 2011 revolution:

[M]ost women are smiling, waving, dandling babies to the tune of the chants ... Old women call: "God be with you [the shabab]! God give you victory!" (17),

and as the mothers of the Egyptian nation at large:

"Shoot us then," they say to the soldiers, "shoot the women. Shoot the mothers of Egypt. Shoot your mothers." (83)

\footnotetext{
${ }^{19}$ For more detail on the historical context that brought Nahdat Misr into existence, going back to the controversy of unveiling women and Mustafa Kamil's statue in 1921, see "Monuments and Sculptures" in Baron 65-66.
} 
On the Day of Wrath when the armed military forces are ordered to kill hundreds of protesting youths, the rhetoric of motherhood intensifies as the martyrs are portrayed as Egypt's young whose "families will spend months of heartbreak finding out and trying to prove how their children were killed" (28).

In addition, Baron locates a tradition of female nationalist writing in Egypt that made use of the family metaphor but avoided masculinist notions of national honor that are grounded in female bodies and their sexual honor (54). In Cairo, Soueif can also be seen as hailing this tradition with her representations of family-inflected, specifically private maternal sites in the city that she invariably transforms into public spaces to shelter the revolutionary cause. One of the earlier images depicted in the narrative is that of Tante Nahed's home in one of the streets that turns into a confrontational zone between the people and the police. The apartment of her deceased uncle's wife comprises a site at which Soueif and other activist relatives regroup and convene to check up on friends and family members, a safe secluded space from where the noise of the public and violence of the revolution could be temporarily shut out (Soueif 19). It evinces a sense of maternal protection and security that characterize other places throughout the city as well, such as the luminescent safety of Soueif's home symbolized by the light left on at the balcony "at night so that I, coming home, or someone coming to visit, can glance up and feel an early welcome" (35).

Parallel to the intra-city sites, Soueif presents from the outset a gendered image of Cairo, one that is largely reminiscent of early $20^{\text {th }}$-century gendered nationalist discourse of the nation: "Degraded and bruised and robbed and exploited and mocked and slapped about: my city. I was ashamed of myself for not saving her. Every one of us was" (45; emphasis added). Not only is Cairo her city, it is also a silent, voiceless city; a feminine, subaltern city, one that is a helpless victim of abuse and must be rescued, a familiar construction that appeals to Western sensibilities. It is interesting that Soueif would juxtapose a strong feminist vibe about the female activists, such as her niece Mona, her sister Laila, and herself, with a deeply intimate, vulnerable, and maternal symbol of Cairo and by extension, Egypt. But it is even more interesting to see that in the above image, the focus is on the beaten-down woman and not on the perpetrator who has committed crimes against her. In other words, Soueif subverts the status quo which reserves speech to the powerful and casts the powerless in silence. She offers her city a platform to find its voice, timid as it may be, recalling how James Hodapp describes this formal act as a writer's stake in representing the postcolonial subaltern from below in "The Postcolonial Joe Sacco" (321). In another striking image of the city, she renders it in feminine rhetoric once again, only this time a maternal link is forged between the city and its people just as it would between a mother and her child:

The city puts her lips to our ears, she tucks her arm into ours and draws close so we can feel her heartbeat and smell her scent, and we fall in with her, and measure our step to hers, and we fill our eyes with her beautiful, wounded face and whisper that her memories are our memories, her fate is our fate. (Soueif 9)

When Soueif does not underscore the revolution with domestic, particularly maternal metaphors on parallel personal and public levels, she builds a repertoire of images of strong women activists from various age groups, social classes, religious backgrounds, and intellectual levels, all of whom play significant, if not 
central roles in the revolution, not in the least because she represents them as vocal characters in the text. One early and prominent image in the narrative is of Soueif running through the streets of downtown Cairo with her nieces as they try to catch up with the revolution and escape the tear gas the police try to scatter people with (20). The girls' father, Soueif's brother, relinquishes the traditional role of patriarchal protector of his family and entrusts his sister with it, she coming across as a powerful, capable matron and activist: "My brother when I called him said his daughters wanted to join the action, and would I take them? This would be their first protest" (19). Without further elaboration on her brother's role in the revolution, Soueif does, however, emphasize that Laila and Mona are actively taking part in the marches and protests (14). One of the recurring impressions she gives the reader of her family is that it is comprised of a group of independent, progressive, nationally activist women. Furthermore, when Soueif makes note of faces she recognizes in the protests, she calls the women by their names and the men by the roles that relate them to these women, an example being her friend Lena and her nameless husband (21; emphasis added). The reader also hears from women on a lower intellectual and social level than Soueif and her family, such as Um Nagla, whom Soueif refers to as "our help," when she speaks about her son Ali's stance on Mubarak's criminal regime: "Ali,' she tells me, 'Ali says of Mubarak and all his men: "Before they open their mouths they're liars; they breathe lies." And this,' she adds, 'is Ali-who-couldn't-speak'" (15). It is also important to note that Soueif identifies her as Nagla's mother ("Um" is the Arabic word for "mother") rather than refer to her with her real name or even as Um Ali, as it is customary in Arab societies to attribute parents' names to their son, if any. Despite attempts to portray women in the memoir as liberal, emancipated figures, it only seems possible either by an inverse silencing of their male counterparts or by embracing filial bonds that empower women as matriarchs who delusionally elide an inescapable patriarchal presence.

We also hear from women with various social standings: Mona Mina, the physician and revolutionary activist is depicted as a tireless heroine saving the lives of young rebels whom the police had injured (33). Karima, Soueif's modest and conservative Muslim neighbor, also leaves the reader with the iconic image of "[taking] off her galabeyya and veil and [putting] on a loose trouser suit and a scarf" (37), indeed a problematic reference to several Muslim feminists' iconic and historical gestures of "unveiling" as signs of women's emancipation and resistance to patriarchy, including Hoda Shaarawi. Soueif revives this particular image without its proper context which registers for Western audiences as a politically liberal act and a rejection of Islam on behalf of women activists in 2011, a depiction that is neither conclusive nor true. Another significant female activist in the memoir is none other than Soueif's niece Mona, portrayed as one of the central actresses who resist the state's enforced Internet blackout when she and the shabab succeed at reconnecting the revolution to the outside digital world and its media networks, again from "someone's mother's apartment," a site of protection and hopefulness (27). It seems as though Soueif is interested in documenting the opinion of women from a cross-class culture who speak the same language of liberation and empowerment, the manner in which Badran envisions the rhetoric of feminism in Egypt as a transclass phenomenon, but she only does so in a pro-secular capacity without bringing to light the persistence of class struggles or conceding to the role played by Islamic feminists in 2011.

Even when weaving in metanarrative material into the memoir's diegetic world, Soueif chooses a moment of confrontation that is experienced and then recounted by a woman to her female friend. This instance 
occurs in the last entry before the section entitled "An Interruption" written in October, eight months after the Tahrir Revolution, in which Soueif uses Mada, a female character from a novel she was working on before the revolution, as a mouthpiece for the Egyptian people and the male soldier as a symbol of daily military oppression:

"Mada" is talking to "Aysa" about the Museum: "You know," says Mada, "it's unbelievable. It's as if the city doesn't even belong to us. A soldier stopped me walking near the Museum in Tahrir the other day. In the centre of Cairo. He said it's forbidden to walk here. I couldn't believe it. 'How d'you mean forbidden?' 'It's forbidden.' I pointed at a whole load of people walking into the Museum. He said they're foreigners. I said so I'm forbidden because I'm not a foreigner? Are you serious? What if I want to go to the Museum? He said why should you go to the Museum? I said haven't you noticed it's called the "Egyptian" Museum? And haven't you noticed this square is called "Liberation" Square? Do you know who it was liberated from? It was liberated from the foreigners, for us: the Egyptian people." "And what did he say?" "He said: 'You'll have to speak to the officer."' (58)

It is also worth noting that the site of confrontation is near the national museum, a symbol of national history and identity to which Mada lays claim on behalf of the sons and daughters of Egypt. Once again, Soueif collapses the distinction between woman and nation, and only empowers one through the other's struggle. Had it not been for Soueif pointing out that this scene is a work of fiction stitched into the larger fabric of the memoir, the reader would not have been able to distinguish it from the bulk of depictions of women's experiences in fighting against state abuse in Tahrir Square.

This is not to say that men are excluded from representation in the memoir. On the contrary, they do factor in to Soueif's version of the revolution. However, they come across as almost exclusively young and intelligent civil actors. In the epilogue where she relinquishes her authorial voice to carry through popular voices, she deliberately selects two men and two women who are family members, to speak their own minds in separate entries in the first person - Mona, Alaa, Sanaa, and Omar Robert:

And because it was the shabab who made this possible, because it was they who changed the world, and it now belongs to them, I want to leave you with some of their voices; the young Egyptians, the young Cairenes, who are working and living our revolution as I put down my pen. (Soueif 187)

However, there are occasions when she lends a rhetorical voice to chosen people couched within her own voice without necessarily attributing them to a particular social class, religious, or political party, enveloping her identity with theirs until they meld into one giant collective being: the people; referred to as "we" or "us." This is manifested in her recollection of a new wave of protests igniting after Friday prayer on January 28, 2011, from a square she was at with her friend, the celebrated civil engineer Mamdouh Hamza (whom she thereafter refers to as $\mathrm{MH}$ ): 
[T]he young man's arm is in the air, his hand reaching to the sky, and there comes the loud, carrying voice: "Al-sha3b yureed isqat al-nizam!" There it was, no lead-up, no halfmeasures; the young man on the shoulders of some fifteen young people. (17; emphasis added)

True as the event may be, the most striking aspect of Soueifs representation is its youthful nature (repeated three times) which projects the illusion of solidarity among popular voices dissenting against the Mubarak regime. This is further established with Soueif's sweeping illustration of countless martyrs who died fighting for this revolution, for liberation: "Some of us died" (23). She counts herself among those people from whose ranks some had fallen. In this case, there is always the sense that Soueif is orchestrating the voices and they all tie back to her - speaking to her or around her. Her voice speaks for the revolutionary people; she is their vehicle unto the global sound stage; their voices and actions in turn embody what the defeatist generation of writers and activists had not been able to accomplish since the student movements in the '70s. ${ }^{20}$ However, if she does not register them, they are not invisible, but neither are they heard. In other words, her pronominal authorial voice gives others a voice by extension for she oscillates between representing herself among the collective solidarity of revolutionary people (the inclusive "we"), and standing apart from them, taking note of their voices, observing them as "they; the shabab." This wavering between self-integration and occlusion from the revolutionary crowd both, mirrored in the fluctuation between using the third-person plural (they) and the first-person collective (we), uncovers the self-isolating quality of writing from the 1990s generation, to which Soueif belongs (Heshmat 69-70), but also attempts to overcome it in the spirit of a more engaged political and personal writing in the $21^{\text {st }}$ century.

Building on this linguistic aspect, the critical reader can further argue that Soueif writes from a privileged position with a stake in portraying a watered-down version of cultural specificity. In other words, she writes about the Egyptian people for the West in a language that could circulate globally and that the West could consume. This manifests in her transliterating Egyptian colloquialisms chanted by the public during the uprisings, such as "'Mesh hanemshi /Enta temshi!" and then translating them into English for the Western reader: "We're not going /You go home!" (160). Additionally, the subtle interspersing of transliterated Arabic idiomatic words and expressions like "shabab," "khalas," "habibti," "habibi," "Allahu Akbar," and the iconic "baltagis," which are imbibed with meaning from their local context and lose meaning in translation, gesture at a form of cultural tourism - a window into a foreign culture for Western readers without offering much local color. She in fact prepares her non-native Arabic-speaking reader for these textual idiosyncrasies in a note on spelling before the book's acknowledgments and preface. We may even see it as an attempt to

\footnotetext{
20 Soueif explains that the armed military forces have cracked down on every potential popular movement since the student movement in 1972 against Anwar Sadat's Israeli-sympathetic policies. The people have been unable to take back Tahrir - both figuratively and literally - from the state and the police until 2011. See page 11 of the memoir.
} 
cater to a local and global reading public simultaneously, rather than "jump" certain publics entirely, to use Brian Edwards' term, and remain faithful to the Egyptian public by preserving its nationalist sentiment. ${ }^{21}$

It has become clear at this point that the biggest weight of representation is reserved for women activists, secular liberalists, and the shabab on the author's side of the revolution, not any state officials or institutions, such as the Security Council of the Armed Forces, the Dakhleyya's Chief of Intelligence of Prisons, and the National Democratic Party. Most governmental discourse and press releases on the state's position with respect to the people and their demands before and during the January revolution are in fact synthesized into abrupt, indirect, and minimalist speech, which suggests that Soueif's image of popular revolt is an exclusive one. Even the Islamists, men and women who also constituted an active participant body in the early uprisings, are not given much verbal or visual weight in the memoir. In the interruptive mid-section, the debate among the revolutionary parties over a draft of the people's demands in July 2011 is, interestingly enough, rendered in abstracted terms: Soueif refers to large camps of people as "the Liberals," "the Islamists," and "the Ikhwan," mentioning only briefly and without historical context that the source of conflict has to do with "past experience and what each group suspects of the other's intentions" (94). She leaves it precariously open-ended with a statement on the following page that reads, "[T]he Islamists will double-cross us," distinguishing thus between the collective "us" fighting for the people's liberation and the Islamists whom in this statement, she does not perceive as part of "her/our" revolution (95). The image she thus constructs of the revolution wants to be inclusive and lay claim to all Egyptians, but it is in fact gendered, and in this gendering, leans almost exclusively towards a certain class of secular women which panders to Western feminist sensibilities. The "our" in "our revolution," which recurs in the memoir's title and preface, is therefore tainted.

\section{Conclusion}

The analysis of revolutionary voices in Soueif's text as attentive to both gender-inflected and familyoriented imagery situates her personal and political account of the 2011 revolution at the edge of a long tradition of women's resistance writing in Egypt. It simultaneously locates her narrative amidst a wave of hybrid autobiographical writing across many intertextual mediums that has intensified since the beginning of the $21^{\text {st }}$ century uprisings in the Arab world, revealing a need and urgency for the self-affirmation of voice and documentation/representation of history from people's perspectives as revolution unfolds. In spite of the memoir's significant representation of women's political participation and vocalism, the bulk of heterological representation of revolutionary vanguards remains indebted to the shabab motif, a young class of both men and women. Soueif's position as an immigrant writer, intellectual, and journalist writing about a deeply domestic revolution for a Western audience using feminist imagery has garnered her narrative lukewarm reception, especially among local Egyptian feminist activists and nationalist writers, and

\footnotetext{
${ }^{21}$ Brian Edwards uses the phrase "jumping publics" in an article on Magdy el Shafee's 2008 graphic narrative Metro: A Story of Cairo, which essentially refers to a writer or translator's deliberate decision to exclude a certain faction of readers through the choice of diction and language.
} 
242 yet a scrambling acceptance among global readers for she represents the Egyptian revolutionaries in exactly the way the West would like to perceive them: young, middle-class, educated secularists who utilize Western social media platforms to get their desire for democratization across.

However, we cannot deny that Soueif's transgeneric attempt at democratizing the voices of youth and tahrir in the revolution and coming to terms with her private past in Cairo has at some instances pushed the boundaries of postcolonial representation in her insistence on the uprising being a popular leaderless revolution, and its people's demands which fall neither in line with Western discourse nor religious fundamentalist discourse. When it comes to using feminist discourse to further the Egyptian cause beyond postcoloniality, we nevertheless find that Soueif falls back into the selfsame symbols and images that echo a fossilized postcolonial discourse as well as colonialist rhetoric of the land's feminization. 


\section{References}

Abdel Nasser, Tahia. "Women's Revolution and Tahrir Memoirs." Al-Ahram Weekly. 12 Feb. 2013. Web. 16 Feb. 2015.

Al-Aswany, Alaa. On the State of Egypt: What Made the Revolution Inevitable. Trans. Jonathan Wright. New York: Vintage Books, 2011.

Al-Musawi, Muhsin Jassim. The Postcolonial Arabic Novel: Debating Ambivalence. Leiden, Boston: Brill, 2003.

Badran, Margot. Feminists, Islam, and Nation: Gender and the Making of Modern Egypt. Princeton, New Jersey: Princeton University Press, 1995.

---. "Margot Badran, author of Feminism in Islam: Secular and Religious Convergences." The Interview. France 24 News. 9 Dec. 2011. Web. 18 Sept. 2015.

Baron, Beth. Egypt as a Woman: Nationalism, Gender, and Politics. Berkeley, Los Angeles, and London: University of California Press, 2005.

Bassiouni, Mohamed. "Students in Revolt." Al-Ahram Weekly. 30 Oct. 2014. Web. 4 Oct. 2015.

Bromley, Roger. "'Giving Memory a Future': Women, Writing, Revolution." Journal for Cultural Research 19.2(2015): 221-232.

Edwards, Brian. "Jumping Publics: Magdy El Shafee's Cairo Comics." Novel: A Forum on Fiction 47.1 (2014): 67-89.

El-Ariss, Tarek. "Fiction of Scandal." Journal of Arabic Literature 43.2/3 (2012): 510-531. Academic Search Complete. Web. 15 Aug. 2015.

El-Wardani, Mahmoud. "Re-published: Hoda Shaarawi Memoirs on Birth of Egypt's Feminism." Al-Ahram Online. 26 Jun. 2013. Web. 16 Feb. 2015.

Heshmat, Dina. "Egyptian Narratives of the 2011 Revolution: Diary as a Medium of Reconciliation with the Political." Commitment and Beyond: Reflections on/of the Political in Arabic Literature since the 1940s. Eds. Friederike Pannewick et al. Wiesbaden: Reichert Verlag, 2015.

Hodapp, James. "The Postcolonial Joe Sacco." Journal of Graphic Novels and Comics 6.4 (2015): 319-330. Iqbal, Razia. "Egyptian writers on the 'unfinished revolution'." The Guardian. 18 Nov. 2011. Web. 5 Sept. 2015.

Kamal, Hala. "Women's Memoirs of the Egyptian Revolution: Mona Prince's Ismi Thawra and Ahdaf Soueif's Cairo: My City, Our Revolution." The Proceedings of the 11th International Symposium on Comparative Literature: Creativity and Revolution. Cairo: Cairo U, 2014.

Lejeune, Philippe. Le Pacte Autobiograqhique. 1973. Trans. Katherine Leary. Ed. Paul John Eakin. Minneapolis: University of Minnesota Press, 1989.

Parker, Nick. "Day of Wrath in Egypt as 62 Killed." The Sun. 29 Jan. 2011. Web. 13 Dec.

Sakr, Rita. Anticipating the 2011 Arab Uprisings: Revolutionary Literatures and Political Geographies. London and New York: Palgrave Macmillan, 2013.

Sameh, Catherine. "Activism and the Academy: Feminisms in the World." Scholar \& Feminist Online 12.1-2 (Fall 2013/Spring 2014). Web. 17 Nov. 2016.

Shenker, Jack. "Egyptian activist Alaa Abd El Fattah accuses army of hijacking revolution." The Guardian. 2 Nov. 2011. Web. 5 Sept. 2015. 
Kohl 2.2

244 Soueif, Ahdaf. Cairo: My City, Our Revolution. London: Bloomsbury, 2012.

---. "In Times of Crisis, Fiction Has to Take a Back Seat." The Guardian. 17 Aug. 2012. Web. 3 Sept. 2015.

Valassopoulos, Anastasia. "Arab Feminisms." Feminist Theory 11.2 (2010): 213-215. Web. 9 Apr. 2015. 